\title{
Militarization, factionalism and political transitions: an inquiry into the causes of state collapse
}

\author{
Daniel Lambach (D) Eva Johais • Markus Bayer
}

Published online: 9 June 2020

(C) The Author(s) 2020

\begin{abstract}
Why do some fragile states collapse while others do not? This article presents results from a comparative analysis of the causes of state collapse. Using a dataset of 15 cases of state collapse between 1960 and 2007, we conduct both synchronic and diachronic comparisons with two different control groups of fragile states using crisp-set QCA. The results support our hypothesis that state collapse has multiple causes. The militarization of political groups, when combined with other conditions, plays a major part in the process. Other causal factors are political transition, extreme poverty, declining government resources or external aid, factionalist politics, repression and pre-colonial polities. This challenges structuralist explanations focusing on regime types and the resource curse, among other things, and opens up avenues for further research.
\end{abstract}

Keywords State collapse $\cdot$ Failed states $\cdot$ Fragile states $\cdot$ QCA

Electronic supplementary material The online version of this article (https://doi.org/10.1007/ s12286-020-00450-9) contains supplementary material, which is available to authorized users.

\section{Lambach $(\bowtie)$}

Forschungsverbund Normative Ordnungen, Goethe-Universität Frankfurt, Max-Horkheimer-Str. 2, 60629 Frankfurt am Main, Germany

E-Mail: lambach@normativeorders.net

E. Johais

Bremen International Graduate School of Social Sciences, Universität Bremen, Mary-Somerville-Str. 9, 28334 Bremen, Germany

M. Bayer

Institut für Politikwissenschaft, Universität Duisburg-Essen, Lotharstr. 65, 47057 Duisburg, Germany 


\section{Militarisierung, Faktionalismus und politische Transitionen: Eine Analyse der Ursachen von Staatskollaps}

Zusammenfassung Warum kollabieren manche fragilen Staaten während andere diesem Schicksal entgehen? Dieser Artikel präsentiert die Ergebnisse einer vergleichenden Untersuchung der Ursachen von Staatskollaps. Auf der Grundlage eines Datensatzes von 15 Fällen von Staatskollaps zwischen 1960 und 2007 unternehmen wir einen synchronen sowie einen diachronen Vergleich mit unterschiedlichen Kontrollgruppen fragiler Staaten mittels crisp-set QCA. Die Ergebnisse stützen die Hypothese, dass Staatskollaps komplexe Ursachen hat. Die Militarisierung politischer Gruppen in Kombination mit weiteren Bedingungen spielt dabei eine zentrale Rolle im Prozess des Staatskollaps. Andere kausale Bedingungen sind politische Transitionen, extreme Armut, sinkende Staatseinnahmen oder externe Unterstützung für die Regierung, faktionalistische Politik, Repression sowie vorkoloniale Polities. Dies fordert strukturalistische Erklärungen heraus, welche auf Regimetypen und den Ressourcenfluch verweisen, und eröffnet Wege für weitere Forschung.

Schlüsselwörter Staatskollaps · Staatszerfall · Fragile Staaten · QCA

\section{Introduction}

Why do some fragile states collapse while others avoid this fate? Recently, Syria, Libya, Mali, Yemen and the Central African Republic have again drawn attention to a phenomenon that had previously been associated with countries like Somalia, Lebanon and the Democratic Republic of the Congo. The events of 9/11 placed it firmly on the global security agenda, with Western policymakers viewing collapsed states as a source of threats ranging from terrorism and organized crime to nuclear proliferation and refugee flows. This has been paralleled by a burgeoning number of academic publications and research projects (Bueger and Bethke 2014).

Despite widespread interest, we still know surprisingly little about the causes of state collapse (Lambach and Bethke 2012). Most scholarly contributions focus on conceptual issues, offer critiques of the overall discourse or discuss policy options for Western countries. This is partly due to a lack of reliable and valid data. Large$\mathrm{N}$ approaches are forced to rely on proxy measures of dubious validity. To address this lacuna, this paper takes a different methodological approach and uses crisp-set Qualitative Comparative Analysis (QCA) to inquire into the causes of state collapse.

We view state collapse as an extreme form of the more widespread, but ill-defined phenomenon of state fragility. In our definition, state collapse is a situation in which formal state institutions have no meaningful capacities in three core dimensions of statehood: 1) making and implementing binding rules, 2) controlling the means of violence, and 3) collecting taxes, for an uninterrupted period of at least six months. Using these criteria, we analyze 15 cases of state collapse in the period 1960-2007 using an original dataset. The first analysis is a synchronic comparison with other fragile states that did not collapse, the second a diachronic comparison of periods of 
collapse with other times of crisis in the same countries that did not result in state collapse.

Our findings indicate that there is no necessary condition for state collapse but there are several combinations of conditions that are jointly sufficient. These conditions are the militarization of political actors, an extremely low per-capita income, a lack of societal cohesion based on precolonial identities and factionalist politics, recent political transition and a decline in state resources. These results challenge some of the more structuralist explanations in the literature and show that state collapse has a complex causal structure distinct from the more general phenomenon of state fragility.

\section{Prior research on the causes of state collapse}

Although fragile, failed and collapsed states ${ }^{1}$ have received a lot of scholarly and policy attention in recent years, there is little systematic research on their causes. In contrast, the theoretical and conceptual literature is vast and makes a broad range of causal claims, often with little empirical grounding. This paper aims to improve and consolidate the empirical foundations of the field.

There have been a few attempts to analyze the causes of state collapse with large-N approaches. Earlier studies were mainly concerned with developing early warning systems (e.g. Baker and Ausink 1996). In these projects, state failure was frequently conflated with other phenomena such as civil war or ethnic conflict and hence the indicators used are relatively general signs of political instability. A case in point is the Political Instability Task Force (PITF, formerly the State Failure Task Force). The PITF uses a very broad understanding of state failure by including four different kinds of crisis: revolutionary wars, ethnic wars, adverse regime change and genocides/politicides (Esty et al. 1995, p. 1). Even though the Task Force has managed to generate models with some degree of predictive power (e.g. Goldstone et al. 2010), their approach is not amenable for causal research due to its overly broad conceptualization of state failure (Lambach and Gamberger 2008).

What little systematic research exists is plagued by inconsistent results and problematic data validity. A comparison of three major studies shows highly divergent findings (see Table 1). The reasons for this are threefold. First, the studies used different specifications of the dependent variable: Iqbal and Starr (2016) use the "Interregnum" value of the Polity score from the Polity IV dataset, Carment et al. (2008) derive their own index and Bertocchi and Guerzoni (2012) use the World Bank's Country Policy and Institutional Assessment (CPIA) score. ${ }^{2}$ Second, they cover very different sets of cases: Iqbal and Starr used all countries with at least

\footnotetext{
1 Although we consider these to be distinct terms, most scholars use them interchangeably. So as not to limit our review on what many would consider semantic grounds, we include in our survey works that use all these terms.

2 All of which are methodologically problematic in their own ways. For instance, the Polity IV Handbook (Marshall and Jaggers 2005) gives no clear guidelines as to how coders are supposed to apply the "interregnum" code.
} 
Table 1 Comparison of Prior Research Findings

\begin{tabular}{|c|c|c|c|}
\hline Independent Variables & $\begin{array}{l}\text { Iqbal and Starr } \\
\text { (2016) }\end{array}$ & $\begin{array}{l}\text { Carment et al. } \\
(2008)\end{array}$ & $\begin{array}{l}\text { Bertocchi and Guerzon } \\
\text { (2012) }\end{array}$ \\
\hline Democracy score & + & - & - \\
\hline Polity score squared & - & - & \\
\hline Civil war & + & & o \\
\hline External armed conflict & + & & \\
\hline $\begin{array}{l}\text { Strikes/riots/ } \\
\text { demonstrations }\end{array}$ & + & & \\
\hline Revolutions/coups/crises & + & & + \\
\hline Level of development & - & - & \\
\hline Trade openness & o & - & o \\
\hline Cold War & - & & \\
\hline Economic growth & & - & - \\
\hline Infant mortality & & + & \\
\hline Risk of ethnic rebellion & & + & \\
\hline Ethnic diversity & & + & o \\
\hline Income inequality & & o & \\
\hline Investment & & & + \\
\hline Natural resources & & & o \\
\hline Primary enrollment & & & o \\
\hline Government expenditure & & & o \\
\hline Inflation & & & o \\
\hline Restricted civil rights & & & + \\
\hline
\end{tabular}

$+=$ Significantly positive effect, $-=$ Significantly negative effect, $o=$ Nonsignificant

500,000 inhabitants during 1946-2000, Carment et al. cover "more than 100 countries" between 1999-2005, while Bertocchi and Guerzoni's dataset contains 41 subSaharan African countries between 1999 and 2007. Third, they use different independent variables with different operationalizations, leading to sometimes contradictory results.

The lack of suitable datasets measuring the degree and quality of empirical statehood has long been a critical impediment to quantitative research. Various projects have tried to develop instruments for quantifying state fragility, the best-known being the Fragile States Index (formerly Failed States Index, FSI) (Baker 2006). The FSI and similar indices are composed of aggregate data covering a wide thematic spectrum from infant mortality and GDP/capita to the deforestation rate. The enormous breadth of component indicators severely limits the content validity of the overall constructs (Margolis 2012). It is not clear what these indices measure-it is certainly not state fragility, but rather a general, unspecific mélange of social, political and/or economic instability. Causal research becomes de facto impossible with these indicators, since most potential causal conditions are already part of the definition of the concept that is to be explained (Bethke 2012).

The lack of sound data is a general impediment to rigorous research. Hence many researchers call for developing new measures of statehood (Bates 2008a, p. 10; Englehart and Simon 2009, p. 110) but there has been no convincing approach that 
fully closes this gap (but see Schlenkrich et al. 2016). The same problem applies to the measurement of possible causes. Data for these variables are not missing at random, since the availability of consistent, national-level data largely depends on the statistical capacity of the state itself. Therefore, we can expect a higher rate of missing data in fragile states. While these gaps can be bridged by various methods of imputation, this is little more than a "least-worst" solution.

Beyond their methodological issues, current quantitative studies have two additional limitations. First, existing studies rely on "pre-existing off-the-shelf-data" (Englehart and Simon 2009, p. 110) previously collected for other purposes. This means that many potentially interesting explanations are not being investigated for want of suitable data, favoring structuralist explanations for which data are much more readily available than for dynamic factors. Yet most authors agree that the political dynamics are especially important in influencing the outome during periods of political crisis (e.g. Bates 2008a).

Second, quantitative approaches assume causality to be a) "unifinal", i.e. variables have the same effect for all cases, b) additive, i.e. the causal effect of independent variables can be isolated from each other (an issue which can be addressed by using interaction terms, but only a small number of these can realistically be included in a model), and c) symmetric, i.e. when A leads to B, not-A will lead to not-B (Wagemann and Schneider 2010, p. 378). However, a close reading of case narratives (e.g. in Rotberg 2003; Zartman 1995) suggest that assumptions a) and b) do not apply to state collapse. Hence, we assume that state collapse is a complex and multicausal process, in line with findings by Grävingholt et al. (2015), Call (2011) and Tikuisis et al. (2015), who identify distinct types of fragile states.

Results of small-N comparative studies also suggest that the process of state collapse is equifinal, i.e. that several different ways can lead to the same outcome. For instance, Englehart (2007) proposes a model of "self-destructive despotism" that shows how governments in Somalia and Afghanistan deliberately destroyed state institutions to remove checks and balances on their exercise of power and prevent rivals from harnessing alternative sources of power. In response, Lambach (2009) argues that Englehart's model cannot explain state collapse in Lebanon and Tajikistan. To account for these cases, Lambach proposes a second causal model of collapse that focuses on the polarization of national politics and the militarization of political actors. Furthermore, qualitative works have identified additional risk factors including, among other aspects, neopatrimonial or personal rule, factionalism, the resource curse, rentierism, ethnic minority rule, a lack of societal cohesion, declining superpower patronage, and regional diffusion patterns (see the summary in Lambach and Bethke 2012). However, it is unclear whether these factors cause state collapse specifically or state fragility more generally, and whether they only apply to single cases or more broadly. 


\section{Theoretical approach}

\subsection{Conceptualization of state collapse}

Our understanding of state collapse is based on an institutionalist understanding of the state in the tradition of Max Weber. ${ }^{3}$ This is due to pragmatic considerations: we need a concept of the state that is amenable to comparative research and that is similar to those approaches that are already being used in research on fragile and collapsed states. Thus, we opt for an ideal-type definition of the state which follows the (sometimes implicit) standard in the literature on fragile states, Weber's institutionalist theory of the state. We reject alternative approaches that frame the state as a provider of governance outputs (Eriksen 2011) for several reasons: first, output approaches take a normative position about which tasks a state should engage in, which is often based on the "OECD model" of statehood. Second, where nonstate actors compensate for the state's incapacity by providing crucial public goods, an output approach will undererstimate the degree of state dysfunctionality. And finally, output approaches usually exhibit a "democracy bias" by including the rule of law or political participation as one of the definitional elements of statehood.

We use Weber's well-known definition of the state as our point of departure: "A compulsory political organisation with continuous operations (politischer Anstaltsbetrieb) will be called a 'state' insofar as its administrative staff successfully upholds the claim to the monopoly of the legitimate use of physical force in the enforcement of its order" (Weber 1978, p. 54). Weber himself exhorted social scientists to think of statehood as a variable: "Even in cases of such social organisation as a state (...) the social relationship consists exclusively in the fact that there has existed, exists, or will exist a probability of action in some definite way appropriate to this meaning" (Weber 1978, p. 27). The corollary is that if the state only exists as a particular likelihood of certain forms of social action, then there must logically be different degrees of statehood.

Therefore, we define the ideal type of the state as an institution that is characterized by monopolies of rule-making, violence and taxation within a defined territory and the population living therein. This institution finds its organisational expression in an administrative apparatus, political organs and bodies for collective decisionmaking. It is represented by symbols and social practices that remind citizens of the existence of the political order. The monopoly of rule-making is inherent in the concept of the state as the institution making binding decisions for society. The monopoly of violence follows logically from the monopoly of rule-making - to enfore its decisions, a state has to be able to implement them even in the face of resistance. The monopoly of taxation is needed to finance the administrative apparatus that enacts and upholds the previous two monopolies. These monopolies imply that no one else is entitled to make binding rules, use violence or collect taxes unless specifically empowered to do so by the state.

States' abilities to exercise this "holy trinity" of monopolies vary considerably. Variation in statehood can be represented as a three-dimensional space (see Fig. 1).

\footnotetext{
3 The following section is based on a more detailed discussion in Lambach et al. (2015).
} 
Fig. 1 Dimensions of statehood Y: Violence

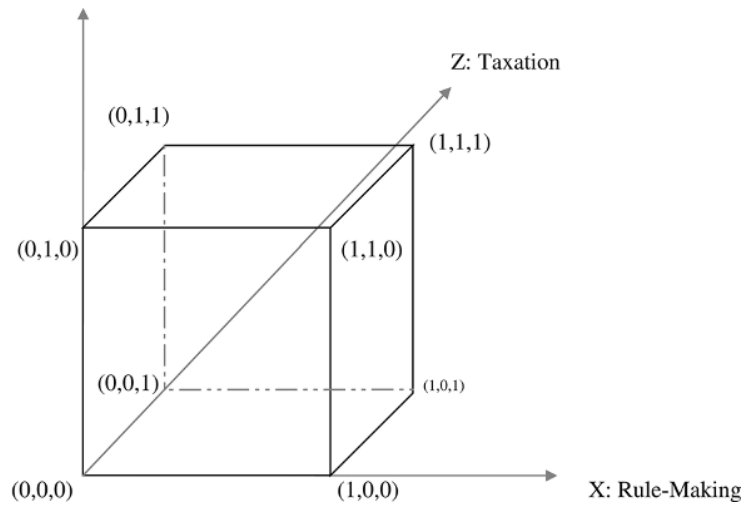

Theoretically, a state can inhabit any point within this space, although some of the extremes are very unlikely to exist in practice. We expect that deficits in one dimension correlate with deficits in the other two, but that is ultimately an empirical question.

Fragile states are close to the $(0,0,0)$ point. It is, however, unclear where the boundaries of this cluster of cases are. Call (2008) and Ulfelder (2012) argue that concepts of state fragility and state failure should be abandoned entirely, since they are too broad and too vague (see also the review by Ferreira 2016). They point out that the line between failed/fragile and non-failed/non-fragile states is impossible to define, and that cases within the group of failed/fragile states are too heterogeneous, which makes comparison almost impossible. We agree with this critique and follow Call's and Ulfelder's exhortation to focus on extreme instances of failure which they call state collapse, borrowing a term from Zartman (1995). We view collapsed states as cases closely clustered around the $(0,0,0)$ point that represent a subset of the larger, ill-defined population of fragile states.

The term state collapse characterizes a condition, not a process, even though a protracted process usually precedes the condition of "collapse". ${ }^{4}$ State collapse, as we understand it, is the binary opposite to our ideal-type of the state. Hence, we define state collapse as a situation in which the state has no significant capacities in all of its three core dimensions, 1) making and implementing binding rules, 2) controlling the means of violence, and 3) collecting taxes, for an uninterrupted period of at least six months. We thereby establish a threshold between the two groups of our comparison, collapsed and non-collapsed fragile states.

\footnotetext{
${ }^{4}$ For analytical reasons, this definition also includes cases in which the state had never had a meaningful presence before (such as the post-independence cases of Bosnia-Herzegovina, Congo-Kinshasa, Georgia and Tajikistan), which would be impossible with a process-oriented definition. This does not mean that we dismiss the processes leading to the outcome of state collapse as insignificant—on the contrary, learning about the interplay of different factors in the causal process is our main research interest.
} 


\subsection{Explaining state collapse}

We draw on theories of state-society relations (Migdal 1988) and elite settlements (Putzel and DiJohn 2012) to explain state collapse. At the intersection of these theories, state institutions are viewed as both socially embedded and co-constitutive with elite relations. Social embeddedness means that the state exists in a space where it competes or cooperates with societal authority figures. Indeed, the state's very raison d'être is bound to its claim to represent some sort of general will, compelling the state to seek recognition for this claim. As for elite settlements, political institutions are not usually the product of conscious design but more a historically contingent reflection of power relationships. Institutions provide a framework for managing elite relations (Geddes 1999) and are sustained by an elite consensus (Dewal et al. 2013). When this consensus changes, institutions must adapt, and where elite coalitions break down, institutions are worn down or swept away. Crucially, if an elite coalition breaks down but is quickly replaced by a new coalition, the state is usually able to re-consolidate while averting collapse.

Our core assumption is that state collapse is best explained by combining structural and dynamic explanations. Structural explanations point to relatively static social conditions while dynamic explanations focus on the agency of political elites and the contingent results of their interaction. These two dimensions cannot be viewed in isolation, very much like the mutual constitution of institutions and elite relations. We therefore view the process leading to state collapse as an escalating power struggle between competing elite factions that weak state institutions are unable to contain (similar to Englehart 2007). To theorize likely causes of state collapse, we derive causal assumptions from several different fields.

First, the literature on fragile statehood and civil war offers explanations for violent power struggles. In line with contract theories of the state (e.g. Ismail 2016; Wagner 2007), it claims that if the formal security apparatus of the state-the military, the police, the judiciary - is unable to deter or punish the use or threat of force by non-state actors, the central legitimizing claim of the state is in question (Posen 1993; Vinci 2006). Likewise, Lambach (2009) points out the detrimental effect of the militarization of political actors in the context of a polarized political system, and Bates et al. (2002) highlight how political actors militarize to gain access to rents (see also Bates 2008b). In some cases, the capacity of formal security institutions is deliberately sabotaged from the inside. Englehart (2007) argues that weak regimes may undermine security forces and the bureaucracy to prevent the formation of alternative power centers within the state. Rulers also sometimes create unofficial militias outside the formal security apparatus, operating under their personal control. These "pro-government militias" (Carey et al. 2013) directly threaten state control of violence even as they prop up the regime.

There is a wealth of theories on how specific modes of governance affect the resilience of state institutions. Concerning transitions to democracy, Bates (2008a, p. 8-9) argues that demands for democratization threaten autocratic incumbents, who turn to predatory and repressive tactics to disrupt the opposition, pushing protesters towards violent rebellion. In a similar vein, Collier cautions that democratization "might at best be a two-edged sword, introducing the possibility of accountability 
but at the price of a greater risk of large-scale political violence" (Collier 2009, p. 233). This literature also suggests repression as a causal condition because it provides citizens with a motivation to mobilize against the government (Saxton 2005), especially if this government only represents, or is perceived to represent, an ethnic minority of the population (Bates 2008a, p. 6-8).

This echoes the macro-historical argument advanced by Acemoglu and Robinson (2012). While their understanding of "failure" is more economic than political, their work fits with other explanations for state collapse. Acemoglu and Robinson focus on the role of institutions in development, arguing that inclusive political and economic institutions decentralize power and lay the foundation for sustainable economic and social development. In contrast, extractive institutions centralize power among the few at the expense of the wider population. Acemoglu and Robinson's core claim is that extractive political institutions create and safeguard extractive economic institutions that transfer wealth to a narrow elite, thus maintaining that elite's privileged position.

However, there are dissenting viewpoints on political institutions, specifically whether particular regime types are more susceptible to state collapse. Whereas Allen (1995) sees autocratic regimes as more prone to state collapse, Carment et al. (2008) consider hybrid regimes as more at risk. Goldstone et al. (2010) broaden this discussion and claim that hybrid regimes with a high degree of factionalism, i.e. a style of politics primarily concerned with parochial interests, are most likely to fail.

A related field of research explores how rent-seeking behavior by elites relates to state collapse, using concepts such as neopatrimonialism, personalism, clientelism, rentierism or informal politics (e.g. Englehart 2007). Rent-seeking practices probably do not cause state collapse by themselves because they are a common feature in almost all fragile states and even in many non-fragile ones. These practices can even stabilize a regime, sometimes for long periods of time, while they erode the institutions on which state authority rests. But this only works if the country's political economy is sound-neopatrimonial and clientelist systems depend on a steady influx of rents. If a sudden decline in government revenues or a reduction of external aid dries up opportunities for personal gain, the ruling coalition will fracture (Allen 1999). Due to the relatively high number of cases in the early 1990s, some observers claim the loss of superpower patronage following the end of the Cold War to be another causal factor of state collapse (e.g. Iqbal and Starr 2016).

Finally, the literature on state formation shows how state-society relations develop over time. Buzan (1991) argues that society needs an "idea" of the state as a legitimate political authority. Tusalem (2016) finds that pre-colonial stateness reduces the likelihood of post-colonial state fragility and Michalopoulos and Papaioannou (2012) show a strong positive association between African pre-colonial polities and contemporary levels of local economic development but these results only hold for cases in which pre- and post-colonial polities are mostly congruent. In contrast, "weblike societies" (Migdal 1988, p. 39) mainly consisting of local associations and traditional authorities without an overarching system of symbols and values represent infertile ground for state-building. Similarly, Boone (2003) shows how strong institutions in rural society impede state-building efforts in African post-colonial 
states. However, due to the ubiquity of these social forms in post-colonial countries, we focus on those that are the most long-lived and thus, presumably, best institutionalized. We thus expect a particularly high risk of collapse in cases in which a localized polity existed in pre-colonial or pre-imperial times that did not cover the entire territory of the post-colonial state. These polities provide a reference point for factionalist politics in the post-colonial political system (but see Wig 2016).

\section{Research design}

Based on our review of the literature, our research design should:

a) be able to deal with equifinal causality,

b) not be limited to structural independent variables,

c) include the collection of original data so as not to rely on proxy variables.

A medium-N research design provides the best fit for these parameters. Compared to small-N designs, this approach allows us to include more explanatory conditions and obtain more representative results. Compared to large- $\mathrm{N}$ designs, our approach is better at dealing with equifinality, i.e. the assumption that different paths can lead to the same outcome (Bennett 2004, p. 38-40), and conjunctural causation, i.e. that variables only exhibit a causal effect in specific combinations (Wagemann and Schneider 2010, p. 378). It is also more manageable to collect original data for a medium number of cases than for a larger one. Finally, there are only a limited number of cases, which militates against most quantitative approaches. ${ }^{5}$

\subsection{QCA}

We use Qualitative Comparative Analysis (QCA) as our method of analysis. ${ }^{6}$ QCA is a tool for the systematic comparison of cases that is grounded in the qualitative tradition of recognizing the importance and unique aspects of each individual case. It assumes that causality is complex, meaning that social phenomena have more than one cause, that these causes interact with each other, and that different instances of the same phenomenon may have different causes. QCA employs Boolean algebra to derive combinations of sufficient and necessary conditions for a particular outcome (in this case, state collapse). QCA fits our research design well because

\footnotetext{
5 The limited number of cases makes parametric tests unfeasible. Due to the structure of the data and the frequency distribution of the phenomenon, estimation is not possible, nor do we believe that the main results can plausibly be deemed valid. This is, first, due to overfitting regarding the ratio of events to nonevents and observations per variable. Studying the causes of state collapse with statistical analysis is likely to result in spurious correlations and error-prone estimates. Modeling complex causality and equifinality via interaction of variables only increases the problem of overfitting. Second, estimating logistic regression models using the two case control samples is not possible due to separation, i.e. because there are single variables or combinations thereof that perfectly predict state collapse.

6 The burgeoning literature on QCA is too large to be reviewed here. Articles by Berg-Schlosser et al. (2009) and Wagemann and Schneider (2010) are good introductions, while the volumes by Schneider and Wagemann (2012) and Rihoux and Ragin (2009) provide more detailed instructions.
} 
its assumptions of equifinality and conjunctural causation are at the core of this approach.

In classic or "crisp-set" QCA (csQCA), both conditions and outcomes are coded in binary. For instance, for the condition "population size", the threshold could be defined as "20 mio. inhabitants". Each case would then be assigned a value of 0 (the state has fewer than 20 mio. inhabitants) or 1 (the state has at least 20 mio. inhabitants). The resulting dataset is summarized in a truth table from which solution terms are derived. Obviously, the dichotomous coding of conditions and outcomes incurs a loss of information about individual cases and may group together very disparate cases that happen to find themselves on the same side of the threshold. Two alternative methods, fuzzy-set QCA (fsQCA, Ragin 2000) and Multi-Value QCA (MVQCA, Cronqvist and Berg-Schlosser 2009), use the same approach as csQCA but allow for more fine-grained conditions. However, csQCA was better suited to our research question than fsQCA, since our aim was to distinguish collapsed states from those that remained fragile. Given the conceptual vagueness of "state fragility" and the likely existence of different subtypes of fragility, establishing meaningful thresholds for different degrees of fragility was not feasible. Hence a dichotomous distinction between membership and non-membership in a set of collapsed states is sufficient for our purposes. We tested whether MVQCA (which also uses a binary outcome variable) added explanatory value over csQCA but ultimately rejected this approach because it made results more complex without offering additional analytical leverage (see Appendix).

In QCA, contradictions and logical remainders require special attention. Contradictions occur when cases with the same set of conditions have different outcomes. There are various strategies for dealing with contradictions, but the general advice is that the number of contradictions should be minimized as much as possible ( $\mathrm{Ri}$ houx and de Meur 2009, p. 48). Logical remainders are combinations of conditions that are not associated with a particular outcome because no empirical case had this particular set of values (the problem of "limited diversity", see Schneider and Wagemann 2012, p. 151-177). It is permissible to make "simplifying assumptions" about how these combinations would have turned out if there had been an empirical case with these characteristics to arrive at a more parsimonious outcome, but care must be taken not to make unrealistic assumptions just to arrive at a better result.

\subsection{Cases}

In a previous paper (Lambach et al. 2015), we identified 17 cases of state collapse between 1960 and 2007. 15 of these cases are included in the present analysis while Afghanistan 2001 and Iraq 2003 were excluded due to the strong impact of foreign military invasion on the stability of the state. Cases are described in country-year format, the year denoting the onset of state collapse (Outcome=1).

We conduct two separate comparisons with different sets of control cases. In both instances, control cases were selected using a matching "Most Similar, Different Outcome" (MSDO) approach (de Meur and Berg-Schlosser 1994). Control cases were fragile states that could have conceivably collapsed but did not during periods of significant crisis (e.g. rebellion, coup, public unrest). In the synchronic 
Table 2 Cases of State Collapse and Control Cases

\begin{tabular}{llllll}
\hline Collapse Case & $\begin{array}{l}\text { Collapse } \\
\text { Year }\end{array}$ & $\begin{array}{l}\text { Synchronic Control } \\
\text { Case }\end{array}$ & Year & $\begin{array}{l}\text { Diachronic Control } \\
\text { Case }\end{array}$ & Year \\
\hline Afghanistan & 1979 & Sri Lanka & 1983 & Afghanistan & 1973 \\
Angola & 1992 & Mali & 1991 & Angola & 1975 \\
$\begin{array}{l}\text { Bosnia-Herze- } \\
\text { govina }\end{array}$ & 1992 & Croatia & 1995 & - & - \\
Chad & 1979 & Ethiopia & 1974 & Chad & 1965 \\
Congo-Kinshasa & 1960 & Nigeria & 1967 & Zaire & 1977 \\
Zaire & 1996 & Sudan & 1992 & - & - \\
Georgia & 1991 & Moldova & 1992 & Georgia & 2003 \\
Guinea-Bissau & 1998 & Lesotho & 1998 & Guinea-Bissau & 1980 \\
Laos & 1960 & Cambodia & 1967 & Laos & 1989 \\
Lebanon & 1975 & Iran & 1979 & Lebanon & 2005 \\
Liberia & 1990 & Burundi & 1993 & Liberia & 1979 \\
Sierra Leone & 1998 & Guinea & 1996 & Sierra Leone & 1967 \\
Somalia & 1991 & Niger & 1990 & Somalia & 1978 \\
Tadjikistan & 1992 & Uzbekistan & 1999 & Tajikistan & 2010 \\
Uganda & 1985 & Burkina Faso & 1987 & Uganda & 1971 \\
\hline & & & & &
\end{tabular}

comparison, we selected one control case per collapse case that was as similar as possible with respect to the following criteria: geographic region; time period; size of population and territory; and level of economic development. ${ }^{7}$ The second control group for the diachronic comparison consists of the same countries as the collapse cases but at other points in time. For the diachronic comparison, we selected instances where a political crisis occurred at least 5 years prior to collapse (but not prior to 1960) or - if such a case was not available — at least five years after the state was no longer collapsed. ${ }^{8}$ While the first comparison is intended to indicate structural differences between collapsed and non-collapsed states, the second is meant to identify dynamic causes of state collapse by asking why collapse occurred at a particular time (Table 2).

\section{Hypotheses and conditions}

We assume the causal structure of state collapse to be deterministic, complex and equifinal. Hence we formulate two simple configurational hypotheses on the causal structure of state collapse:

\footnotetext{
${ }^{7}$ We tried to identify periods of instability in the control cases that are temporally as close as possible to the onset of collapse in the respective positive case. The maximum deviation between collapse case and matched control case is seven years: Congo Kinshasa 1960-Nigeria 1967; Laos 1960-Cambodia 1967; Tadjikistan 1992-Uzbekistan 1999.

8 There is no control case for Bosnia-Herzegovina because it cannot be considered a fully sovereign state from 1995 onwards due to the ongoing de facto trusteeship of the international community. Furthermore, we use no more than one diachronic control case per country, so there is only one control case (Zaire 1977) for both collapse cases of Congo-Kinshasa 1960 and Zaire 1996.
} 
$\mathbf{H}_{1}$ : No individual condition, or combination of conditions, is necessary for state collapse.

$\mathbf{H}_{2}$ : There exist combinations of conditions drawn from our literature review that are sufficient for state collapse.

$\mathrm{H}_{2}$ represents a combination of INUS conditions. INUS stands for "Insufficient but Nonredundant part of an Unnecessary but Sufficient condition". Mahoney describes INUS conditions as

parts of larger combinations of factors that are jointly sufficient for outcomes.

Thus, while an INUS condition is itself neither necessary nor sufficient for an outcome, it is part of a larger combination of factors that is sufficient for an outcome (Mahoney 2010, p. 131, fn. 22).

We treat potential explanatory conditions as (combinations of) conditions that can be "plugged into" these configurational hypotheses. We focus on nine conditions, which are summarized in Table 3. ${ }^{9}$ Whenever valid data was available in other datasets, we used this as a basis for our coding. For some conditions, we had to collect our own data, usually from secondary literature about cases (these are marked as "qualitative research" in the "Source" column). This entailed the production of detailed case studies for all 43 cases (15 collapse cases, 15 synchronic control cases, 13 diachronic control cases). To maximize the reliability of coding decisions, a set of detailed coding rules were developed, briefly summarized in the column "Description and coding rules". ${ }^{10}$

\section{QCA results}

For both comparisons, the number of conditions (nine) is too large for meaningful results. Marx (2006) suggests a maximum ratio of 0.33 conditions per case $(0.25$, if there are 6-7 conditions, 0.2 for 8 conditions). For our comparison of 30 and 28 cases, respectively, this leaves an upper bound of seven conditions. Marx and Dusa (2011) give even lower numbers to minimize the risks of random results.

Checking for necessity, we found no single condition present in all instances of collapse. We began by testing sets of seven conditions by treating two pairs of conditions as substitutes for each other due to their conceptual similarity: MILIT and UNOFF_MILITIA, and AID and GOV_REV. ${ }^{11}$ These sets produced solutions without contradictions but with highly idiosyncratic terms covering only a small

\footnotetext{
${ }^{9}$ For a discussion of some alternative conditions and their results, see the Appendix.

10 The codebook and the dataset are available at https://dataverse.harvard.edu/dataverse/statecollapse and https://www.daniellambach.de/research/.

11 We treat the first pair as potential substitutes based on the empirical observation that there is only a single case (Georgia 2003) in which unofficial militias are present but there is no general militarization of all relevant political actors (MILIT is almost a necessary condition for UNOFF_MILITIA). Regarding the second pair, the decrease in government revenues and the reduction of international aid both constitute a decline of resources available for maintaining the established formal and informal institutions of the state. Thus we assume that these conditions trigger a similar dynamic affecting the resilience of states.
} 


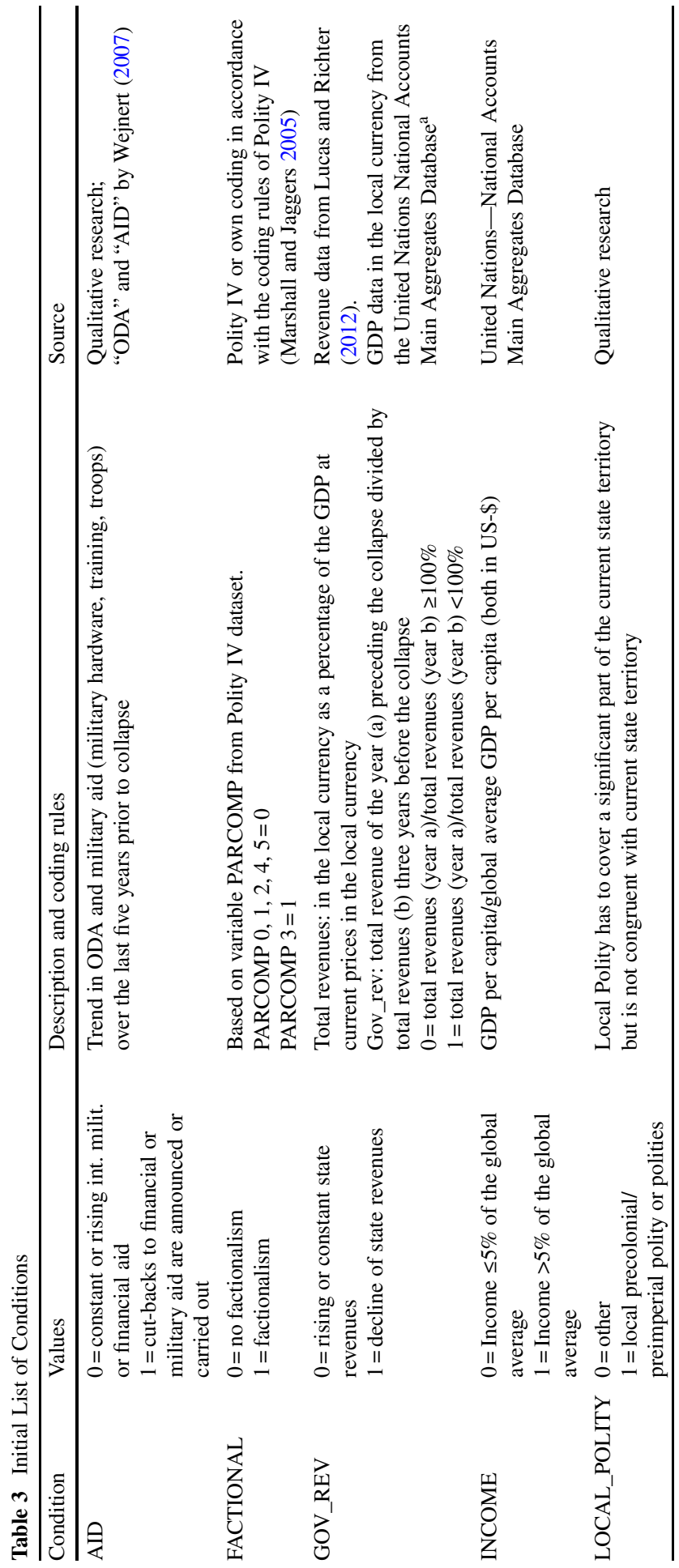




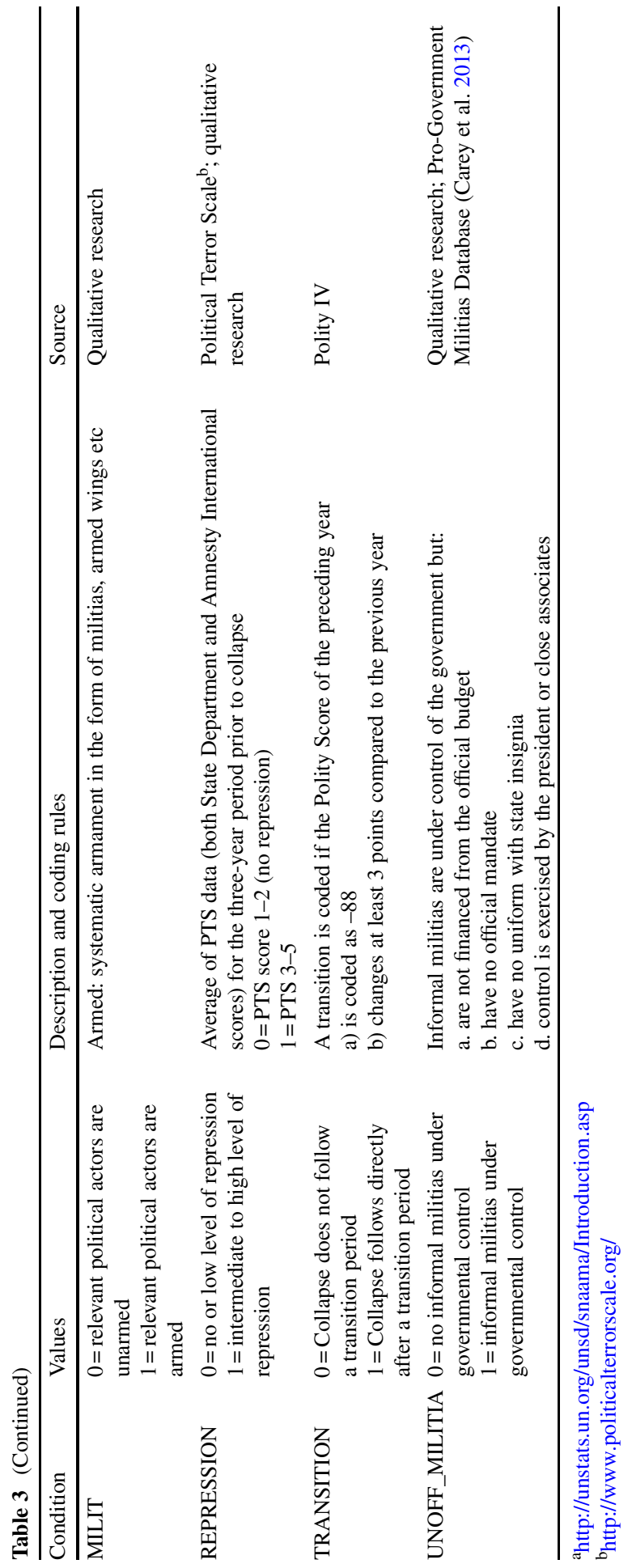


Table 4 Solution for Outcome $=1$ and Coverage of Solution Terms (Synchronic Comparison)

\begin{tabular}{|c|c|c|c|}
\hline Term & Cases covered & $\begin{array}{l}\mathrm{RC} \\
(\%)\end{array}$ & $\begin{array}{l}\mathrm{UC} \\
(\%)\end{array}$ \\
\hline $\begin{array}{l}\operatorname{MILIT}(1) * \mathrm{IN}- \\
\operatorname{COME}(0)\end{array}$ & $\begin{array}{l}\text { Sierra Leone } 1998+\text { Uganda } 1985+\text { Somalia } 1991 \text {, } \\
\text { Chad 1979+ Liberia 1990+Laos } 1960\end{array}$ & 40 & 13.3 \\
\hline $\begin{array}{l}\text { MILIT(1) } * \\
\text { GOV_REV(1) }\end{array}$ & $\begin{array}{l}\text { Sierra Leone } 1998+\text { Somalia 1991, Chad } \\
\text { 1979+ Tajikistan 1992, Bosnia-Herzegovina 1992, } \\
\text { Georgia 1991 + Afghanistan 1979+ Angola } 1992\end{array}$ & 53 & 33.3 \\
\hline $\begin{array}{l}\text { INCOME }(0) * \text { LO- } \\
\text { CAL_POLITY }(1)\end{array}$ & $\begin{array}{l}\text { Sierra Leone } 1998 \text { + Uganda } 1985 \text { + Somalia } 1991 \text {, } \\
\text { Chad 1979+Zaire 1996 + Guinea-Bissau } 1998\end{array}$ & 40 & 13.3 \\
\hline $\begin{array}{l}\text { FACTIONAL(1)* } \\
\text { MILIT }(1) * \text { LO- } \\
\text { CAL_POLITY }(1)\end{array}$ & $\begin{array}{l}\text { Sierra Leone } 1998+\text { Uganda } 1985+\text { Congo-Kinshasa } \\
\text { 1960, Lebanon } 1975\end{array}$ & 26.7 & 13.3 \\
\hline
\end{tabular}

$R C$ raw coverage, $U C$ unique coverage

Cases that are unique to a particular term are highlighted in italics

number of cases each. To lower the number of conditions, we tested which conditions could be dropped from the analysis to identify sets of five conditions that still produced solutions without contradictions. ${ }^{12}$

\subsection{Synchronic comparison}

The synchronic comparison highlights the presence of unofficial militias as a sign of imminent state collapse. The consistency level of UNOFF_MILITIA(1) as a sufficient condition for state collapse amounts to 0.9 with a coverage of 0.6 . Only a single control case (Sudan 1992) has this condition, preventing complete sufficiency.

In the synchronic comparison, the only combination of five conditions that produces a truth table without contradictions is FACTIONAL, GOV_REV, INCOME, MILIT and LOCAL_POLITY. The parsimonious solution and the cases covered by individual terms are given in Table 4.

This formula can be summarized as follows:

$$
\begin{aligned}
& \text { MILIT }(1) *[\operatorname{INCOME}(0)+\text { GOV_REV }(1)+\text { FACTIONAL }(1) \\
& * \text { LOCAL_POLITY }(1)]+\operatorname{INCOME}(0) * \text { LOCAL_POLITY }(1)
\end{aligned}
$$

The solution formula contains four alternative paths that explain the outcome of state collapse in the synchronic comparison. The militarization of politics is an INUS condition in three of these paths, appearing in conjunction with either a) extreme poverty (national GDP $<5$ per cent of the global average per capita income), b) a recent decline of government revenues, and c) the existence of local pre-colonial polities combined with factionalized political competition. The fourth path to the outcome includes extreme poverty and the pre-colonial/pre-imperial

\footnotetext{
12 Results were obtained using fsqca 3.0 (Ragin and Davey 2014) and reproduced with TOSMANA Version 1.54 (Cronqvist 2017). Sensitivity checks were conducted by recoding or recalibrating some of the conditions. We use the parsimonious solution for both comparisons, as these solutions rely on theoretically plausible simplifying assumptions. See the Appendix for truth tables and further details.
} 
Table 5 Solution for Outcome $=1$ and Coverage of Solution Terms (Diachronic Comparison)

\begin{tabular}{|c|c|c|c|}
\hline Term & Cases covered & $\mathrm{RC}(\%)$ & $\mathrm{UC}(\%)$ \\
\hline TRANSITION(1) & $\begin{array}{l}\text { Afghanistan 1979, Chad 1979+ Angola 1992+ Congo- } \\
\text { Kinshasa 1960+ Laos 1960+ Sierra Leone 1998, Tajik- } \\
\text { istan } 1992\end{array}$ & 46.7 & 13.3 \\
\hline $\begin{array}{l}\text { FACTIONAL (1) * } \\
\text { MILIT(1) }\end{array}$ & $\begin{array}{l}\text { Bosnia-Herzegovina 1992, Georgia 1991, Lebanon } \\
\text { 1975+ Congo-Kinshasa 1960+ Laos 1960+ Sierra Leone } \\
\text { 1998, Tajikistan 1992 + Uganda } 1985\end{array}$ & 53.3 & 20 \\
\hline $\begin{array}{l}\text { REPRESSION }(1) * \\
\operatorname{AID}(1)\end{array}$ & $\begin{array}{l}\text { Angola 1992 + Zaire 1996+ Guinea-Bissau } \\
\text { 1998+ Liberia 1990, Somalia 1991 + Sierra Leone 1998, } \\
\text { Tajikistan } 1992\end{array}$ & 46.7 & 26.7 \\
\hline
\end{tabular}

$R C$ raw coverage, $U C$ unique coverage

Cases that are unique to a particular term are highlighted in italics

existence of local polities in parts of the territory of post-colonial states or those states that emerged from the breakup of multinational empires.

\subsection{Diachronic comparison}

In the diachronic comparison, TRANSITION is a sufficient condition for state collapse but with a coverage of only 0.4 . In other words, seven collapsed states had undergone political transition within the year prior to collapse but this explains the timing of state collapse only in a minority of cases. As in the synchronic comparison, UNOFF_MILITIA(1) is almost sufficient, with a consistency of $90 \%$ and a coverage of $60 \%$. Again, only a single control case (Georgia 2003) also has unofficial militias.

As in the synchronic comparison, we were able to find a single truth table with five conditions that is entirely free of contradictions: MILIT, TRANSITION, REPRESSION, AID and FACTIONAL. Computing the parsimonious solution by including logical remainders produces the result presented in Table 5.

The diachronic solution formula shows three proximate "paths" to state collapse. Political transition in the immediate pre-collapse period is a sufficient condition for state collapse. The combination of factionalism and militarized political competition represents another path-the relevance of these two factors is underscored by the results of the synchronic comparison. A third path consists of a high level of repression and a decline of external financial and/or military aid.

These results support our conjunctural hypotheses. There are no single necessary conditions for state collapse $\left(\mathrm{H}_{1}\right)$ but there are combinations of factors that are jointly sufficient for the outcome $\left(\mathrm{H}_{2}\right)$. The sole exception is that a single condition-transition-was a sufficient cause for some cases in the diachronic comparison. None of these combinations covered all cases of collapse however, neither in the synchronic nor in the diachronic comparison.

\section{Discussion}

Our synchronic and diachronic comparisons produce somewhat different results. Two factors - the militarization of political actors and factionalist politics-were 
present in both solutions. Both explanations also featured some form of declining state access to resources, either through a drop in revenues (synchronic) or through the reduction of international aid (diachronic). The results diverge with respect to the additional factors: the remaining two conditions from the synchronic solution are an extremely low level of per capita income and the existence of local, precolonial polities, both clearly structural factors. In contrast, the diachronic comparison's solution formula includes two more dynamic factors, namely recent political transition and a high level of repression. This is in line with our theoretical reasoning that the synchronic comparison highlights structural differences between collapsed and non-collapsed states, while the diachronic comparison identifies dynamic differences between situations of collapse and non-collapse within the same country.

Results from both comparisons do not provide us with neat groups of cases that share similar structural characteristics and follow similar trajectories. Instead, most cases are covered by different combinations of solution terms, preventing us from constructing a clear and meaningful taxonomy of cases. For instance, both BosniaHerzegovina 1992 and Afghanistan 1979 were covered by the term MILIT(1) * GOV_REV(1) in the synchronic comparison. But whereas Bosnia-Herzegovina 1992 was covered by the term FACTIONAL(1) * MILIT(1) in the diachronic comparison, Afghanistan 1979's solution term was TRANSITION(1). However, some cases are grouped together under similar terms in both comparisons. Afghanistan 1979, Chad 1979, and Angola 1992 show up in the same solution terms in both comparisons. This is also true for Lebanon 1975, Congo-Kinshasa 1960 and Uganda 1985. Likewise, Bosnia-Herzegovina 1992, Georgia 1991 and Tajikistan 1992 are grouped together in both results, which is unsurprising since they had all recently become independent at the time of collapse. While a closer comparison of these groups of countries could be enlightening, the results are still ambiguous, since many cases are covered by multiple solution terms in at least one of the comparisons. On its own, QCA does not provide us with sufficient information as to which of these multiple solutions should be preferred. Hence, the membership of cases in solution terms should be seen as an invitation for more focused research, not as the endpoint of this line of inquiry.

There are also some general ways of interpreting our results. The majority of solution terms in the synchronic comparison include the condition of a militarization of political actors. ${ }^{13}$ The term with the highest raw and unique coverage-MILIT(1) * GOV_REV(1) — covers several newly independent countries (Bosnia-Herzegovina, Georgia, Tajikistan) that were faced with militant uprisings at a time when government finances were in severe disarray, limiting the state's ability to counter these insurgencies. A similar process can also be observed in other covered cases like Sierra Leone, Angola and Somalia. Another solution term, MILIT(1) * INCOME $(0)$, hints at a comparable situation but the INCOME condition is difficult to interpret,

\footnotetext{
13 Notably, when UNOFF_MILITIA replaces MILIT, solution coverage decreases in both comparisons. This is somewhat surprising, since the existence of unofficial pro-government militias is close to a sufficient condition in both comparisons. The importance of this deviation should not be overstated, however, as MILIT is almost a necessary condition for UNOFF_MILITIA - there is only a single case in the entire dataset (the synchronic control case Georgia 2003) that has UNOFF_MILITIA(1) and MILIT(0).
} 
possibly indicating low state revenues, low opportunity costs for rebellion, or the destruction of economic assets from prior civil wars.

FACTIONAL(1) * MILIT(1) * LOCAL_POLITY(1) suggests an intriguing scenario in which political actors militarize against the backdrop of factionalist politics that refer to pre-colonial identities. This interpretation can be illustrated by some of the cases covered by this solution term: ethnic politics in Uganda, regionalist factionalism in Congo-Kinshasa and confessional identities in Lebanon all provided a resource for militant mobilization against the state. The last solution term in the synchronic comparison, INCOME(0) * LOCAL_POLITY(1), lends itself to a similar interpretation. In most cases covered, e.g. Zaire, Guinea-Bissau, Somalia or Chad, local identities represented an important survival mechanism in desperately poor countries. These two terms underscore the importance of a collectively shared idea of statehood. Strong local identities with deep historical roots seem to have a divisive effect.

In the diachronic comparison, the sufficiency of TRANSITION(1) is intuitively compelling - periods of political change are times of uncertainty about the future distribution of power, which create incentives for political actors to escalate latent conflicts and increase risks of state collapse. However, this solution term is unique for only two of the seven cases covered (Afghanistan and Chad), so the causal effect of transition on its own is limited. This is further supported by the large number of political transitions not associated with state collapse. To reconcile these findings, future research is necessary to establish under which circumstances political change leads to state collapse.

Another solution term, FACTIONAL(1) * MILIT(1), uses the same conditions as some of the terms from the synchronic comparison. Interpreting these in more dynamic terms, we suggest another interpretation of factionalism in terms of political strategy. By playing up differences, political elites set off processes of in-/ outgrouping which, in combination with the militarization of political actors, initiate an escalatory spiral, as we can observe in cases like Bosnia-Herzegovina, Georgia or Lebanon. Finally, REPRESSION(1) * AID(1) has a high unique coverage and offers a fairly specific explanation for several cases in which autocratic regimes relying on repression were weakened by a reduction of external financial or military aid at a time when their domestic opposition was getting more militant and more capable. This pattern can be found mainly in African cases, such as Zaire, Guinea-Bissau, Liberia and Somalia, where superpower patronage tailed off after the end of the Cold War.

\section{Conclusion}

Using QCA is a novel approach for the field, addressing several shortcomings of previous research by accounting for the equifinal and conjunctural causality of the phenomenon. Moreover, QCA enables systematic testing of qualitative conditions that lack the scale of measurement required for statistical methods. Our results point to different combinations of factors that undermine the stability of state institutions. The complexity of these results confirm our assumption that the causal processes 
leading to state collapse are heterogeneous and cannot be boiled down to singular or mono-causal explanations. It is also noteworthy how many theoretical arguments were not supported. This includes Englehart's argument about regimes obstructing state bureaucracies and security forces, Lambach's hypothesis that political polarization matters, Acemoglu and Robinson's theory of exclusive institutions, the supposed dangers of ethnic minority rule, or the resource curse (see Appendix).

This suggests that existing theories and empirical studies should be revisited. On the one hand, our results agree with some findings from the quantitative analyses surveyed above, for instance that underdevelopment is associated with the risk of collapse (Iqbal and Starr 2016; Carment et al. 2008). They also resonate with Bates et al.'s (2002) formal model of the emergence of private actors of violence in failing states. On the other hand, we found no evidence that regime type has any explanatory value, as Iqbal and Starr (2016), Carment et al. (2008) and Bertocchi and Guerzoni (2012) allege (see Appendix). Our findings also shed some light on the relationship between state collapse and civil war. Where previous studies differed as to whether there was a positive correlation between the occurrence of civil war and state failure (Iqbal and Starr 2016) or not (Bertocchi and Guerzoni 2012), we find that the militarization of political actors is a crucial condition for state collapse. This is in line with Aliyev's (2017) findings that it is not civil war but the presence of violent non-state actors that increases the risk of state failure.

Furthermore, it is apparent that state collapse is something more specific than state fragility, with its own set of causes, in contradiction to Bertocchi and Guerzoni (2012, p. 777), who see little difference between the two. We therefore regard arguments that the root causes of state fragility and state failure are structural (e.g. Ismail 2016) as too simplistic. Structural causes matter, but our results indicate that dynamic processes are just as important for explaining state collapse. We find that both aspects need to be considered to make sense of why (and when) some fragile states collapse while others do not.

This also highlights innovative directions for further research. First, the militarization of political actors obviously plays a crucial role. This may be partly due to our conceptualization of state collapse (see Lambach et al. 2015), but we believe that the military dynamics of collapse processes deserve more attention. Second, the role of political transition has been primarily discussed in relation to the risk of civil war (e.g. Cederman et al. 2010) but has received less attention in the literature on state collapse. Finally, the impact of factionalist politics and the continuing relevance of pre-colonial polities suggest that shared identities are very important for maintaining stable societies, but this again is poorly understood in the literature.

Moving beyond the immediate QCA results, there are additional avenues for further research. The first would be to think more systematically about the relationship of institutions and elite politics in constituting political order. One example of such an approach is the notion of "political settlements" which Putzel and DiJohn define as "the distribution of power between contending social groups and social classes" (Putzel and DiJohn 2012, p. 1). Their approach focuses on contention and bargaining among elites, between elites and non-elites, and between social groups. Similar approaches have been used in research on democratic stability (Dewal et al. 2013). Second, the significance of militarization as a causal condition highlights the need 
to further investigate the connection between large-scale violence and state collapse. On a conceptual level, we should revisit the question concerning to what extent, and at which level of intensity, violence should be part of the definition or operationalization of state collapse. This needs to include literatures on civil wars and state formation, which show that violence can also create and sustain political order as much as destroy it (e.g. Hampel 2015). Such a broader way of theorizing would go some way towards problematizing the assumption that functioning formal state institutions guarantee stability and peace.

We are aware that our approach has its limitations. In our case, combining synchronic and diachronic comparisons made it difficult to formulate a parsimonious explanation. Furthermore, QCA does not allow us to make inferences about causal relations between conditions and the outcome variable. This is acknowledged by Schneider and Wagemann-who otherwise present QCA and other set-theoretic methods as useful for causal analysis (2012, p. 8) - when they discuss post-QCA within-case studies as a method for "unraveling the causal mechanisms that link the condition to the outcome" (Schneider and Wagemann 2012, p. 308; also see Schneider and Rohlfing 2013). While our results give us some confidence that there may be a causal relation between the solution terms and state collapse, this requires further scrutiny. Hence our discussion of possible explanations should be read as hypothesizing about plausible mechanisms, not as definitive truth claims.

The next step of our project will be to triangulate the QCA results with other methods to test whether the conditions highlighted in the solution terms had a meaningful causal effect on the outcome of cases, either individually or in conjunction with each other. This is in line with QCA best practices which exhort researchers to shift from comparative analysis to within-case analysis and back again as the research progresses (Ragin 2000, p. 283; Rihoux and de Meur 2009, p. 65-66; Schneider and Wagemann 2012, p. 305-312). Using the QCA solution terms as a starting point, we will use comparative process-tracing to analyze whether the conditions and their combinations exert a discernible causal effect and if so, via which mechanisms (Beach and Pedersen 2013). This will allow us to tackle the problem of two distinct solutions which make theory-building concerning the causes of state collapse difficult.

Acknowledgements This research was made possible by the generous funding of the German Research Foundation (Deutsche Forschungsgemeinschaft, Grant No. LA 1847/8-1). Earlier versions of this paper were presented at the 8th Pan-European Conference on International Relations, Warsaw, 18-21 September 2013 and the 55th Annual Convention of the International Studies Association, Toronto, 26-29 March 2014. Christian Tischmeyer, Laura Blomenkemper, Simon von Dahlen and Jörg Langerwisch provided research assistance. We thank Wiebke Breustedt, Jörg Faust, Achim Goerres, Jörn Grävingholt, Julia Leininger, Benoît Rihoux and Claude Rubinson and editors and reviewers at multiple journals for their helpful comments. We are also indebted to Felix Bethke for methodological advice, Thomas Richter for supplying us with data on state revenues, and Lasse Cronqvist and Sascha Werthes for technical and logistical support.

Funding Open Access funding provided by Projekt DEAL.

Open Access This article is licensed under a Creative Commons Attribution 4.0 International License, which permits use, sharing, adaptation, distribution and reproduction in any medium or format, as long as you give appropriate credit to the original author(s) and the source, provide a link to the Creative Commons licence, and indicate if changes were made. The images or other third party material in this article 
are included in the article's Creative Commons licence, unless indicated otherwise in a credit line to the material. If material is not included in the article's Creative Commons licence and your intended use is not permitted by statutory regulation or exceeds the permitted use, you will need to obtain permission directly from the copyright holder. To view a copy of this licence, visit http://creativecommons.org/licenses/by/4. $0 /$.

Conflict of interest D. Lambach, E. Johais and M. Bayer declare that they have no competing interests.

\section{References}

Acemoglu, Daron, and James A. Robinson. 2012. Why nations fail: the origins of power, prosperity and poverty. London: Profile Books.

Aliyev, Huseyn. 2017. Precipitating state failure: do civil wars and violent non-state actors create failed states? Third World Quarterly 38:1973-1989.

Allen, Chris. 1995. Understanding African Politics. Review of African Political Economy 22:301-320.

Allen, Chris. 1999. Warfare, endemic violence and state collapse in Africa. Review of African Political Economy 26:367-384.

Baker, Pauline H. 2006. The conflict assessment system tool (CAST): an analytical model for early warning and risk assessment of weak and failing states. Washington DC: Fund for Peace.

Baker, Pauline H., and John A. Ausink. 1996. State collapse and ethnic violence: toward a predictive model. Parameters 26:19-31.

Bates, Robert H. 2008a. State failure. Annual Review of Political Science 11:1-12.

Bates, Robert H. 2008b. When things fell apart: state failure in late-century Africa. Cambridge: Cambridge University Press.

Bates Robert, H., Avner Greif, and Smita Singh. 2002. Organizing violence. Journal of Conflict Resolution 46:599-628.

Beach, Derek, and Rasmus B. Pedersen. 2013. Process-tracing methods: foundations and guidelines. Ann Arbor: University of Michigan Press.

Bennett, Andrew. 2004. Case study methods: design, use, and comparative advantages. In Models, numbers, and cases: methods for studying international relations, ed. Detlef Sprinz, Yael Wolinsky-Nahmias, 19-55. Ann Arbor: University of Michigan Press.

Berg-Schlosser, Dirk, Gisèle De Meur, Benoît Rihoux, and Charles C. Ragin. 2009. Qualitative Comparative Analysis (QCA) as an Approach. In Configurational comparative methods. Qualitative comparative analysis (QCA) and related techniques, ed. Benoît Rihoux, Charles C. Ragin, 1-18. Los Angeles: SAGE.

Bertocchi, Graziella, and Andrea Guerzoni. 2012. Growth, history, or institutions. Journal of Peace Research 49(6):769-783

Bethke, Felix S. 2012. Zuverlässig invalide-Indizes zur Messung fragiler Staatlichkeit. Zeitschrift für Vergleichende Politikwissenschaft 6:19-37.

Boone, Catherine. 2003. Decentralization as political strategy in west Africa. Comparative Political Studies 36:355-380.

Bueger, Christian, and Felix Bethke. 2014. Actor-networking the 'failed state': an enquiry into the life of concepts. Journal of International Relations and Development 17:30-60.

Buzan, Barry. 1991. People, states and fear, 2nd edn., New York: Harvester Wheatsheaf.

Call, Charles T. 2008. The fallacy of the 'failed state. Third World Quarterly 29:1491-1507.

Call, Charles T. 2011. Beyond the 'failed state': toward conceptual alternatives. European Journal of International Relations 17:303-326.

Carey, Sabine C., J. Mitchell Neil, and Will Lowe. 2013. States, the security sector, and the monopoly of violence: a new database on pro-government militias. Journal of Peace Research 50:249-258.

Carment, David, Yiagadeesen Samy, and Stewart Prest. 2008. State fragility and implications for aid allocation: an empirical analysis. Conflict Management and Peace Science 25:349-373.

Cederman, Lars-Erik, Simon Hug, and Lutz F. Krebs. 2010. Democratization and civil war: empirical evidence. Journal of Peace Research 47:377-394.

Collier, Paul. 2009. The political economy of state failure. Oxford Review of Economic Policy 25:219-240.

Cronqvist, Lasse. 2017. Tosmana: tool for small-N analysis. Version 1.54. Trier: University of Trier.

Cronqvist, Lasse, and Dirk Berg-Schlosser. 2009. Multi-Value QCA (mvQCA). In Configurational comparative methods. Qualitative comparative analysis (QCA) and related techniques, ed. Benoît Rihoux, Charles C. Ragin, 69-86. Los Angeles: SAGE. 
Dewal, Snigdha, Jack A. Goldstone, and Michael Volpe. 2013. Forecasting stability or retreat in emerging democratic regimes. Politics and Governance 1:32-47.

Englehart, Neil A. 2007. Governments against states: the logic of self-destructive despotism. International Political Science Review 28:133-153.

Englehart, Neil A., and Marc V. Simon. 2009. Failing states and failing regimes: the prediction and simulation of state failure. In Dealing with failed states: crossing analytic boundaries, ed. Harvey Starr, 108-127. London: Routledge.

Eriksen, Stein S. 2011. 'State failure' in theory and practice: the idea of the state and the contradictions of state formation. Review of International Studies 37:229-247.

Esty, Daniel C., Jack A. Goldstone, Ted R. Gurr, Pamela T. Surko, and Alan N. Unger. 1995. State failure task force report. McLean: Science Applications International Corporation.

Ferreira, Ines A. 2016. Measuring state fragility: a review of the theoretical groundings of existing approaches. Third World Quarterly 38:1291-1309.

Geddes, Barbara. 1999. What do we know about democratization after twenty years? Annual Review of Political Science 2:115-144.

Goldstone, Jack A., Robert H. Bates, David L. Epstein, Ted R. Gurr, Michael B. Lustik, Monty G.Marshall Jay Ulfelder, and Mark Woodward. 2010. A global model for forecasting political instability. American Journal of Political Science 54:190-208.

Grävingholt, Jörn, Sebastian Ziaja, and Merle Kreibaum. 2015. Disaggregating state fragility: a method to establish a multidimensional empirical typology. Third World Quarterly 36:1281-1298.

Hampel, Karl A. 2015. The dark(er) side of 'state failure': state formation and Socio-political variation. Third World Quarterly 36:1629-1648.

Iqbal, Zaryab, and Harvey Starr. 2016. State failure in the modern world. Stanford: Stanford University Press.

Ismail, Abdirashid A. 2016. The political economy of state failure: a social contract approach. Journal of Intervention and Statebuilding 10:513-529.

Lambach, Daniel. 2009. Warum kollabieren Staaten? In Identität, Institutionen und Ökonomie: Ursachen innenpolitischer Gewalt Politische Vierteljahresschrift Sonderheft Nr. 43., ed. Margit Bussmann, Andreas Hasenclever, and Gerald Schneider, 235-257. Wiesbaden: VS.

Lambach, Daniel, and Felix S. Bethke. 2012. Ursachen von Staatskollaps und fragiler Staatlichkeit: Eine Übersicht über den Forschungsstand. INEF-Report No. 106/2012. Duisburg: Institut für Entwicklung und Frieden.

Lambach, Daniel, and Dragan Gamberger. 2008. A temporal analysis of political instability through subgroup discovery. Conflict Management and Peace Science 25:19-32.

Lambach, Daniel, Eva Johais, and Markus Bayer. 2015. Conceptualizing state collapse: an institutionalist approach. Third World Quarterly 36:1299-1315.

Lucas, Viola, and Thomas Richter. 2012. Taxation, distribution and authoritarian regime longevity: evidence from the global state revenues and expenditures data set. Paper presented at the Annual Meeting of the American Political Science Association, New Orleans, 30 August-2 September 2012.

Mahoney, James. 2010. After KKV: the new methodology of qualitative research. World Politics 62:120-147.

Margolis, J. Eli. 2012. Estimating state instability. Studies in Intelligence 56:13-24.

Marshall, Monty G., and Keith Jaggers. 2005. Polity IV project: political regime characteristics and transitions, 1800-2004-Dataset users' manual. Vienna, VA: George Mason University, Polity IV Project.

Marx, Axel. 2006. Toward more robust model specification in QCA: results from a methodological experiment. COMPASSS Working Paper 43:1-25.

Marx, Axel, and Adrian Dusa. 2011. Crisp-set qualitative comparative analysis (Csqca), contradictions and consistency benchmarks for model specification. Methodological Innovations Online 6:103-148.

de Meur, Giséle, and Dirk Berg-Schlosser. 1994. Comparing political systems: establishing similarities and dissimilarities. European Journal of Political Research 26:193-219.

Michalopoulos, Stelios, and Elias Papaioannou. 2012. Pre-colonial ethnic institutions and contemporary African development. NBER Working Paper 18224. Washington: National Bureau of Economic Research.

Migdal, Joel S. 1988. Strong societies and weak states. State-society relations and state capabilities in the third world. Princeton: Princeton University Press.

Posen, Barry R. 1993. The security dilemma and ethnic conflict. In Ethnic conflict and international security, ed. Michael E. Brown, 103-124. Princeton: Princeton University Press.

Putzel, James, and Jonathan DiJohn. 2012. Meeting the challenges of crisis states. London: Crisis State Research Centre. 
Ragin, Charles C. 2000. Fuzzy-set social science. Chicago: University of Chicago Press.

Ragin, Charles C., and Sean Davey. 2014. fs/QCA [Computer Programme], Version 3.0. Irvine: University of California.

Rihoux, Benoît, and Gisèle de Meur. 2009. Crisp-set qualitative comparative analysis (Csqca). In Configurational comparative methods. Qualitative comparative analysis (QCA) and related techniques, ed. Benoît Rihoux, Charles C. Ragin, 33-68. Los Angeles: SAGE.

Rihoux, Benoît, and Charles C. Ragin (eds.). 2009. Configurational comparative methods. Qualitative comparative analysis (QCA) and related techniques. Los Angeles: SAGE.

Rotberg, Robert I. (ed.). 2003. State failure and state weakness in a time of terror. Washington: Brookings Institution Press.

Saxton, Gregory D. 2005. Repression, grievances, mobilization, and rebellion: a new test of Gurr's model of ethnopolitical rebellion. International Interactions 31:87-116.

Schlenkrich, Oliver, Lukas Lemm, and Christoph Mohamad-Klotzbach. 2016. The contextualized index of statehood (CIS): assessing the interaction between contextual challenges and the organizational capacities of states. Zeitschrift für Vergleichende Politikwissenschaft 10:241-272.

Schneider, Carsten Q., and Ingo Rohlfing. 2013. Combinding QCA and process tracing in set-theoretic multi-method research. Sociological Methods \& Research 42:559-597.

Schneider, Carsten Q., and Claudius Wagemann. 2012. Set-theoretic methods for the social sciences. A guide to qualitative comparative analysis. Qualitative Comparative Analysis (QCA) and Fuzzy Sets. Cambridge: Cambridge University Press.

Tikuisis, Peter, David Carment, Yiagadeesen Samy, and Joseph Landry. 2015. Typology of state types: persistence and transition. International Interactions 41:565-582.

Tusalem, Rollin F. 2016. The colonial foundations of state fragility and failure. Polity 48:445-495.

Ulfelder, Jay. 2012. 'State failure' has failed. How about giving 'state collapse' a whirl? http:// dartthrowingchimp.wordpress.com/2012/07/05/state-failure-has-failed-how-about-giving-statecollapse-a-whirl/. Accessed 4 Feb 2020.

Vinci, Anthony. 2006. The 'problems of mobilization' and the analysis of armed groups. Parameters 36:49-62.

Wagemann, Claudius, and Carsten Q. Schneider. 2010. Qualitative comparative analysis (QCA) and fuzzy-sets: agenda for a research approach and a data analysis technique. Comparative Sociology 9:376-396.

Wagner, Robert H. 2007. War and the state. Ann Arbor: University of Michigan Press.

Weber, Max. 1978. Economy and society. Berkeley: University of California Press.

Wejnert, Barbara. 2007. Nations, Development, and Democracy, 1800-2005. ICPSR20440-v1. http://www. icpsr.umich.edu/icpsrweb/ICPSR/studies/20440. Accessed 4 Feb 2020.

Wig, Tore. 2016. Peace from the past: pre-colonial political institutions and civil wars in Africa. Journal of Peace Research 53:509-524.

Zartman, I. William (ed.). 1995. Collapsed states: the disintegration and restoration of legitimate authority. Boulder: Lynne Rienner. 